\title{
COMPOSITION AND PERFORMANCE CAN BE, AND OFTEN HAVE BEEN, RESEARCH
}

\author{
Ian Pace
}

\begin{abstract}
John Croft's article 'Composition is not Research' challenges a conception and ideal of compositional work in academia which has grown in prominence over several decades in the UK. As a performer-scholar, who also writes non-performance-related scholarship, I welcome this challenge, share some of Croft's reservations about the ways in which these conceptions often manifest themselves, and also have concerns about the rushed integration of practitioners into academia and the implications for more traditional forms of scholarship. However, I find many of Croft's formulations and assumptions too narrow, and instead argue that a good deal of the process of composition and performance does constitute research - grappling with difficult questions, exploring solutions, and producing creative work which embodies these solutions and from which others can draw much of value.
\end{abstract}

John Croft's article ${ }^{1}$ raises many important issues and has already served as a catalyst for a wider debate. I welcome this, although my own conclusions on the subject are quite different from his. Much literature on practice-as-research in several disciplines is written by those who stand personally to gain from wider acceptance of the concept and the lack of more sceptical voices leads to a lop-sided treatment. ${ }^{2}$ Croft's work in some ways acts as a counterbalance in this respect; what he identifies is a by-product of a British higher education sector in which many boundaries between university and conservatoire music departments have been broken down. ${ }^{3}$ This is in marked contrast to the situation in Germany, for example, with its non-negotiable

\footnotetext{
${ }^{1}$ John Croft, 'Composition is not Research', TEMPO, Vol. 69, No. 272 (2015), pp. 6-11.

2 Lauren Redhead, 'Is Composition Research?' (17 January 2012), at http://weblog.laurenredhead. eu/post/16023387444/is-composition-research\#disqus_thread (accessed 6 September 2015), whilst making some important points, relies on partisan attempts to close down debate with statements like 'claiming that composition is not research can be seen as merely a technique of dividing researchers and distracting attention away from the fact that research might not be what the REF would have us all believe that it is'. Solidarity amongst composers to protect their own corner is unlikely to convince sceptics with less of a vested interest, especially considering the lack of a clearly articulated alternative definition of research in this article.

${ }^{3}$ One of the few essays considering this phenomenon and its implications in this context, in this case focusing upon the Australian situation, is Huib Schippers, 'The Marriage of Art and Academia: Challenges and Opportunities for Music Research in Practice-based Environments', Dutch Journal of Music Theory, Vol. 12, No. 1 (2007), pp. 34-40.
} 
doctorate + Habilitation qualification in order to obtain a permanent position in a university department, that few practitioners will have obtained unless they have developed large-scale elaborate theoretical frameworks, and demonstrated expertise in a second subject too.

But this blurring of boundaries raises as many questions as it solves, many of which have only been addressed by a few of those working in the sector. Historically, university departments have provided a broad field of study and research in music, within which performance in particular is not necessarily a central activity, while conservatoires have always had high-level professional training at their heart. The exclusivity or otherwise of this training depended upon the programme undertaken (performer's course, graduate course, degree course, etc.), but the distinction with a university remained clear. In some ways it still does: there is intense competition for conservatoire places and many of those studying in university departments would be unlikely to gain entry. The situation is less stark the other way round, not least because most university departments have a much more pressing need to recruit students than do most conservatoires. Nowadays, as conservatoires gain degree-awarding powers of their own, they are employing more academic musicians and becoming more embroiled in the funding opportunities offered by the Research Excellence Framework (REF), although this has had less effect upon most instrumental and vocal teachers (and their equivalent in non-academic positions in university departments) than upon composers.

Crucially, if one comes to study composition, whether at a university or conservatoire, is one seeking to learn essential technical skills, or to engage with a much wider reflective and critical approach to composition? The distinction may seem clear, but I am not convinced that all students at such institutions, or their teachers, are really so drawn towards the latter option. The same question applies to performance, creating further difficulties when numbers are bolstered by the acceptance of students who simply want to perform and make a career of that, and are resistant to more critical thinking. The need for student satisfaction and demonstrations of 'vocationality' (replete with employment statistics for marketing purposes) demanded by management can make unreflective and technically-focused courses the safest of options. But as composers and performers are integrated into the full academic structure of university departments, there is pressure on them to produce research; I am not arguing that Croft is necessarily advocating this state of affairs, but it is one of the reasons his article has attracted such widespread discussion.

I would like to broaden the discussion to include performance as well as composition, not least to challenge a perceived hierarchy in academia in this respect. There are many more individuals whose primary activity is composition than performance in full academic positions in UK universities with music departments (one or more composers in practically every department, performers much rarer). Furthermore, performers often face greater difficulties in having their work accepted as research: a quite typical example is a comment from an academic from a non-artistic field who, when presented with the fact that non-text outputs accounted for $42 \%$ of REF 2014 submissions in music, ${ }^{4}$ expressed surprise that this category would include

\footnotetext{
${ }^{4}$ REF 2014 Panel Overview Reports: Main Panel D at http://www.ref.ac.uk/panels/panelover viewreports/ (accessed 6 September 2015), pp. 94-6.
} 
composition, which was viewed narrowly as the production of 'texts'. Those whose work is almost exclusively in the form of the journal article, book chapter or monograph can find it very hard to view something in sonic rather than written form (let alone a live event, not a recording) as research.

There are certainly many difficulties in assessing both composition and performance according to existing academic research criteria. Both elude the possibility of peer review in the manner familiar for text-based outputs, and although various scholars in practice-based fields are considering ways in which equivalents to these processes might be established, ${ }^{5}$ this investigation remains in its early stages. I also believe that equivalence of 'academic' and practice-based $\mathrm{PhDs}$ has been taken too much for granted, ${ }^{6}$ a subject I will return to at the end of this article, and that the quality of the latter has frequently been assessed by parties who are far from disinterested.

The framing of practice-as-research - a radical concept which should be distinguished from practice-led research or research-based practice, each of which can be mapped onto Christopher Frayling's 1993-94 tripartite of research 'through', 'into', 'for' art and design respectively ${ }^{7}$ - can simply constitute a means for integrating practitioners into academia without requiring they fundamentally change the types of outputs they would expect to produce. However, as has been demonstrated in other disciplines, such an integration can open up possibilities for and stimulate forms of work that might not otherwise have been considered. Musicians and musicologists have only very occasionally participated in the wider and sophisticated discourses on these issues developed by scholars and practitioners in other artistic disciplines, above all theatre, who have embraced practice-as-research. ${ }^{8}$ Croft's article does not engage with these

\footnotetext{
5 See Hazel Smith and Roger T. Dean, 'Introduction', in Practice-Led Research, Research-Led Practice in the Creative Arts, ed. Hazel Smith and Roger T. Dean (Edinburgh: Edinburgh University Press, 2009), pp. 25-8 and John Adams, Jane Bacon and Lizzie Thynne, 'Peer Review and Criteria: A Discussion', in Practice-as-Research in Performance and Screen, ed. Ludivine Allegue, Simon Jones, Baz Kershaw and Angela Piccini (Basingstoke: Palgrave Macmillan, 2009), pp. 98-110 for an outline of some of the issues and problems here. Thynne points out that funding bodies assessing practice-as-research are not required to look at the actual work, only at accompanying reports. It is clear that review and assessment processes designed for written work need re-calibrating in order to deal with practice-as-research. The solution presented by Schippers, reasonably forsaking evidence of ticket sales or circulation (which as he says 'would probably make Kylie Minogue the greatest musicologist in Australia'), but offering instead 'presentations in prestigious venues or by organisations', because 'they suggest some form of peer review' ('The Marriage of Art and Academia', p. 37) is immensely problematic because of the wealth of factors involved in economies of prestige, many of them far from transparent or accountable.

${ }^{6}$ Intelligent thoughts on practice-based $\mathrm{PhDs}$ and their assessment can however be found in John Freeman, Blood, Sweat \& Theory: Research through Practice in Performance (Oxfordshire: Libri, 2010), pp. 35-43, 233-9; and Robin Nelson, 'Supervision, Documentation and Other Aspects of Praxis', in Practice as Research in the Arts: Principles, Protocols, Pedagogies, Resistances, ed. Robin Nelson (Basingstoke: Palgrave Macmillan, 2013), pp. 71-92.

7 Christopher Frayling, 'Research in Art and Design', Royal College of Art Research Papers 1/1 (1993-94), p. 5. Swedish theatre scholar Yvla Gislén provided a map in 2006 for the emergence of 'research in the artistic realm' in various countries, beginning in Finland in the 1980s-90s and Australia in 1987, followed by the USA in the 1990s and EU in the late 1990 s, with its emergence in the UK around 1997. This map is reproduced in Baz Kershaw, 'Practice as Research through Performance', in Practice-Led Research, Research-Led Practice, p. 106. Kershaw himself notes that practice was not explicitly part of the criteria for the RAE in the UK until 1996, when practice-as researchers were asked for the first time for a 'succinct statement of research content' and 'supporting documentation' (ibid. p. 111). The most recent definition of research employed by the REF can be found in REF 2014: Assessment framework and guidance on submissions, at http:/ / www.ref. ac.uk/media/ref/content/pub/assessmentframeworkandguidanceonsubmissions/GOS\% 20including\%20addendum.pdf (accessed 24 September 2015), p. 48.
} 
discourses at all, many of which would have set many of his arguments and positions (and especially his definitions of 'research') into relief. For example, his standpoint is countered by brilliant examples of practice-as-research such as Henry Daniel's dance-based Skin, created at Transnet, Vancouver, which became the focus for a set of objectives coming out of a wider tour, incorporating studiobased dance into a wider cross-disciplinary discourse, re-focusing the dancer/performer/undergraduate student in the role of a 'research assistant', and looked to create new guidelines for wider practices-as-research; ${ }^{9}$ Dianne Reid's video choreography aimed to answer the question of how to make her sweat bead on the surface of the TV screen through a work encapsulated in 12 sub-headings relating to its structure and thematic content; ${ }^{10}$ Jane Goodall's framing of specialist knowledge, in this case relating to popular fiction, on Renaissance science and other sources, formed an essential part of a research process leading to the production of her own thriller fiction, in a way which is more enlightening than hackneyed talk of intertextuality. ${ }^{11}$ All of these are not merely new frames, but new species of practice.

Croft's article appeared too early to have been able to engage with the first substantial monograph on practice-as-research in music, a collection less ambitious or adventurous than other publications mentioned, but nonetheless a worthwhile addition to the literature, including a few truly theoretically rigorous and cogent essays. ${ }^{12}$ This had

${ }^{8}$ Music does not feature at all in Estelle Barrett and Barbara Bolt, eds, Practice as Research: Approaches to Creative Arts Enquiry (London: I.B. Tauris, 2010), despite featuring a range of major case studies in other creative and performing arts, and mostly appears in passing in Nelson, Practice as Research in the Arts, though there are a few notable observations about some different views of composition and performance in this respect (pp. 7-8); the major example cited by Nelson is John Irving's research into Mozart performance on the basis of physical interaction with the Hass clavichord (p. 10). This rather paltry attention is however symptomatic of a wider isolation of music from other collective work in creative arts research. One case study by Yves Knockaert in Freeman, Blood, Sweat \& Theory, pp. 200211, deals with a highly imaginative audiovisual Lied project examined in terms of gender, voice, space and image, whilst another, pp. 240-61, on the work of Johannes Birringer, deals with both sound and visuality. Andrew R. Brown and Andrew Sorensen, in 'Integrating Creative Practice and Research in the Digital Media Arts', in Smith and Dean, Practice-Led Research, Research-Led Practice, pp. 153-65, discuss their use of digital media in order to establish a practice surrounding visual and audio-visual exhibitions, drawing upon experience of computer music and music-related software. There is also a short relevant section by Henry Spiller, 'University Gamelan Ensembles as Research', in Shannon Rose Riley and Lynette Hunter, Mapping Landscapes for Performance as Research: Scholarly Acts and Creative Cartographies (Basingstoke: Palgrave Macmillan, 2009), pp. 171-8.

9 Henry Daniel, 'Transnet: A Canadian-Based Cased Study on Practice-as-Research, or Rethinking Dance in a Knowledge-Based Society', in Allegue et al, Practice-as-Research, pp. $148-62$.

10 Dianne Reid, 'Cutting Choreography: Back and Forth between 12 Stages and 27 Seconds', in Barrett and Bolt, Practice as Research, pp. 47-63.

11 Jane Goodall, 'Nightmares in the Engine Room', in Smith and Dean, Practice-Led Research, Research-Led Practice, pp. 200-7. This example in particular deals with Croft's objections to how research methods are inimical to the creative process. It might however be better described as research-led practice rather than practice-as-research.

12 Mine Doğantan-Dack, ed., Artistic Practice as Research in Music: Theory, Criticism, Practice (Farnham: Ashgate, 2015). Among the more substantial contributions to this volume are Anthony Gritten's rather abstract 'Determination and Negotiation in Artistic Practice as Research in Music', pp. 73-90, dealing with the process of establishing Artistic Practice as Research $(\mathrm{APaR})$ as a respectable academic subdiscipline, entailing a turn away from 'pure' research, delineating different manifestations to this, including some undertaken outside of academic institutions, whilst urging that the distinction between practice and research be maintained though its practitioners should relax (not always so easy in institutions, especially those with small performing arts components, in which practiceas-research has still to gain acceptance from various strata of management); and Jane W. Davidson, 'Practice-based Music Research: Lessons from a Researcher's Personal History', pp. 93-106, tracing the author's own work, from a background in music 
been preceded by a special issue of the Dutch Journal of Music Theory in $2007^{13}$ and the Swedish Journal of Musicology in 2013, the latter more focused upon the looser European concept of 'artistic research'; ${ }^{14}$ Croft does not engage with the work contained in either of these journals either, in which he might have found at least more nuanced considerations of the ways in which the various expectations and criteria of research can be fruitfully applied to practice, which itself can be construed as entailing knowledge and understanding.

Certainly Croft makes some important points, particularly the suggestion that the concept of composition-as-research privileges certain approaches, such as those using elaborate compositional systems and/or cutting-edge technology, regardless of the results. To these I would add intricate aesthetic formulations drawing liberally upon canonical 'theorists', or the self-conscious situating of one's practice relative to whichever other composers seem opportune for the careerminded. With respect to the issue of systems, however, Croft's claim that 'good and bad music can be made from any system' is glib, and suggests the systems' role is essentially arbitrary; on the contrary, some crude systems are unlikely to produce good music.

Croft's basic formulation that composition is not intrinsically research is one I accept in this naked form, and I would say the same about performance. But both are outputs, which can entail a good deal of research. A new type of blancmange or smartphone may not themselves be intrinsically research either (nor, as Lauren Redhead vitally points out, is writing), ${ }^{15}$ but few would have a problem seeing them as valid research-based outputs. Croft talks about technical explorations, such as ways to electronically sustain a note without it sounding mechanical, or the production of theoretical treatises, as research informing composition, but the composition itself is not research; he is simply describing research-based practice. Ultimately his model of research seems to require a particular type of conceptually based knowledge which can be communicated verbally, which I find too narrow.

In other ways, Croft's portrayal and definitions of research can seem myopic and even rather haughtily superior, and do not constitute a significant advance on Piers Hellawell's more elaborately argued essay on the subject. ${ }^{16}$ Here one can sense special pleading:

psychology, through study of the body in performance, then 'talk-aloud' approaches in which musicians are encouraged to verbalise their mental processes, to opera directing.

13 Dutch Journal of Music Theory, Vol. 12, No. 1 (2007). Notable essays here include Marcel Cobussen, 'The Trojan Horse: Epistemological Explorations Concerning Practice-based Research', pp. 18-33, which considers both fundamental incompatibilities between music and language and also the idea that music can embody other types of knowledge than concrete ideas, including that of a corporeal nature as found in performance; and on similar issues Tom Eide Osa, 'Knowledge in Musical Performance: Seeing Something as Something', pp. 51-7, also focusing upon non-verbal knowledge; Various other essays are more pragmatic and relatively straightforward, relating to the use of instruments and techniques.

14 Swedish Journal of Musicology, Vol. 95 (2013). In this volume, the questions raised by Cobussen and Osa are explored further in Erik Wallrup, 'With Unease as Predicament: On Knowledge and Knowing in Artistic Research on Music', pp. 25-40, and Cecilia K. Hultberg, 'Artistic Processes in Music Performance: A Research Area Calling for Inter-Disciplinary Collaboration', pp. 79-95. On the distinctions between Anglosphere practice-as-research and continental European artistic research, see Darla Crispin, 'Artistic Research and Music Scholarship: Musings and Models from a Continental European Perspective', in Doğantan-Dack, Artistic Practice as Research in Music, pp. 5372, and Luk Vaes's response to John Croft, 'When composition is not research' (5 June 2015), at http://artisticresearchreports.blogspot.co.uk/2015/06/when-composition-is-notresearch.html (accessed 6 September 2015).

15 See Redhead, 'Is Composition Research?' 
Croft and Hellawell appear to want all the benefits, financial and otherwise, of secure university positions, jobs which are sometimes envied by more traditional academic researchers in an overcrowded academic workplace, but without being subject to the demands made on those other types of academics.

A good piece of composition probably cannot be encapsulated by a series of research questions (except perhaps in some cases of Konzeptuelle Musik), but many aspects of the composition can be productively informed by them. The examples proffered by Croft are yes/no questions, rarely as fruitful in any context as 'hows', 'whys' and so on. Indeed some questions can themselves be answered in a non-verbal manner through creative work. ${ }^{18}$ Brian Ferneyhough's Sonatas for String Quartet could be framed in terms of the question is it possible to sustain a large-scale composition with extensive use of a post-Webernian vocabulary, and if so, how? ${ }^{19}$ For me Ferneyhough's piece avows that this is indeed the case, but that was not necessarily self-evident when he began the composition; a good deal of research went into the process and the nature of the resulting sonic output is far from straightforward, constituting a nuanced and multi-faceted response to the question. Croft's example of Beethoven's Ninth can also be framed in terms of a variety of questions to do with the possibility of expansion whilst preserving certain formal properties: how to integrate voices into the symphony (at which structural moment should one first introduce soloists or the choir? What type of music should occur on this first occasion, and should it be pre-empted earlier by instruments? If a soloist or soloists on this occasion, how would this moment relate to the music of the choir when they enter?). ${ }^{20}$ I agree that we hear Beethoven 'composing himself into a corner, necessitating a radical way out of the resulting musical impasse', but that is a predicament with which many historians or archaeologists, say, will recognise as they try to find a coherent model which incorporates a range of fragmentary, confusing and contradictory primary source material.

I regularly ask myself questions about the music I play, such as 'how is it possible to maintain interest, momentum and sonic diversity in a contrapuntal texture without obviously foregrounding one voice above all others?' or 'how can one maintain a sense of overall

${ }^{16}$ Piers Hellawell, 'Treating Composers as Researchers is Bonkers', Standpoint (May 2014) at http://standpointmag.co.uk/ critique-may-14-treating-composers-as-researchers-bonkerspiers-hellawell (accessed 6 September 2015).

17 Hellawell even goes so far as to say that it feels very much as if composers face a stiff interview - in what for some is a foreign language - before they may sit down to the dinner, despite being encouraged nonetheless to empty their pockets once the bill arrives'. One might imagine from this that composers are paying to work in academia, not being paid for doing so.

${ }^{18}$ This point is emphasised by Brown and Sorensen, in 'Integrating Creative Practice and Research in the Digital Media Arts', p. 153, as well as Cobussen, 'The Trojan Horse', Osa, 'Knowledge in Musical Performance', Wallrup, 'On Knowledge and Knowing in Artistic Research on Music', and Hultberg, 'Artistic Processes in Music Performance'.

19 This is discussed in Andrew Clements, 'Brian Ferneyhough', Music and Musicians, 26/3 (1977), pp. 36-9; Brian Ferneyhough, 'Interview with Andrew Clements' (1977), in Ferneyhough, Collected Writings, edited James Boros and Richard Toop (Amsterdam: Harwood Academic Publishers, 1995), pp. 204-16; and Jonathan Harvey, 'Brian Ferneyhough', The Musical Times, 120/1639 (1979), pp. 723-8.

${ }^{20}$ Michael Naimark, drawing upon the ideas of Nam June Paik, cites Beethoven, and specifically the Ninth Symphony, as an example of where 'art does not really start to get going until an area of practice is established' (in this case earlier by Haydn), as a form of 'lastword' art which is impossible without critical engagement with prior practice. See Naimark cited in Simon Biggs, 'New Media: The 'First Word' in Art?', in Smith and Dean, Practice-Led Research, Research-Led Practice, p. 79. 
coherence in performance whilst maintaining a sense of fragmentation and non-closure? ${ }^{21}$ These are complex questions, which continue to emerge in different contexts, and possible answers are far from selfevident. In some cases I have abandoned the quest, but that is the nature of research; other scholars have also doggedly pursued a hypothesis over an extended period of time only to abandon it when they find it irreconcilable with data to hand.

Contrary to Croft's claim, much research does indeed disregard swathes of previous research when it is not particularly relevant or useful for the task in hand, and rejects unwanted influences (some historians of nineteenth-century Germany have worked hard to move away from the Sonderweg theory, for example; ${ }^{22}$ some looking at the Chartists in Britain have tried to shake off much of the baggage of earlier Marxist interpretations ${ }^{23}$ ). Croft also criticises the need to specify the nature of an original contribution before a work is even composed, but it should be pointed out that a similar problem exists for written academic research when one has not yet devoured sources, archives, done field work, let alone interpreted what is to be found there. Composers are far from alone in finding such demands difficult to sustain.

Croft claims that certain research questions come down to whether one can write music that convinces oneself. In one sense this is of course true, but the business of needing to convince others - whether performers, audiences, funding bodies, promoters, or whoever exists well beyond the academic world; most art is subject to judgement by others who may not share the view of its creator, and this is no bad thing. He dislikes the idea that the purpose of a musical composition is to 'report findings'; so do I. But that is not the only possibility: it can be an output that applies findings and in the process puts them to the test more vividly than a purely theoretical output might be able to. John Cage's HPSCHD, for example, embodies the findings of a particular approach in a way I am happy to call research. ${ }^{24}$

The narratives of 'impact' are very problematic for practitioners, because of the difficulty in measuring them. But many have done so successfully, and in ways I do not believe simply constitute trickery. Compositional achievements can beget other achievements, as can achievements in performance, and of course each can inform the other, as well as informing work in other artistic disciplines and other scholarship. If we were beholden to 'the number of people that hear a piece', it would be impossible to claim impact for much radical contemporary music compared to its commercial counterparts; I for one am glad that the definition is not simply a populist one.

${ }^{21}$ One of the most extreme manifestations of this explicitly questioning approach to performance can be found in the work of Stephen Emmerson and Angela Turner in Around a Rondo, featuring extensive dissection of choices in interpreting Mozart's Rondo in A minor, $\mathrm{K} 511$, presenting the findings of such research on a DVD-ROM, discussed in Schippers, 'The Marriage of Art and Academia', p. 36.

22 See for example Richard J. Evans, 'The Myth of Germany's Missing Revolution', in Rethinking German History: Nineteenth-Century Germany and the Origins of the Third Reich (London: HarperCollins, 1987), pp. 93-122.

23 See Gareth Stedman Jones, 'Rethinking Chartism', in Languages of Class: Studies in English Working Class History 1832-1982 (Cambridge: Cambridge University Press, 1983), pp. 90178.

${ }^{24}$ For another good example, see Graeme Sullivan's account of Cézanne's attempt to break with conventional practice in order to embody a dynamic world, incorporating multiple perspectives, framed as an attempt to address complex theoretical questions in order to arrive at an artistic output which itself entails new knowledge and ideas, in 'Making Space: The Purpose and Place of Practice-led Research', in Smith and Dean, Practice-Led Research, Research-Led Practice, pp. 41-3. 
Does Croft really believe his own description of the compositional process: picking up a pencil, starting at the beginning, stopping when the piece is finished (does he never work on sections in an order different from that of the final work?), maybe asking performers some questions? Most composers regularly ask themselves a great many questions when composing, often relating these to wider ideas and paradigms, even if working alone. What is being asked, not unfairly, of a composer employed in a research-intensive university is that at the least they verbally articulate the questions, issues, aims and objectives, and stages of compositional activity, to open a window onto the process and offer the potential of use to others. As a performer I am happy to do this (and wish more performers would do so) and I do not see why it should be a problem for composers too (the argument that this is unnecessary, as all of this can be communicated solely through the work itself, is one I find too utopian).

Reticence on the part of some practitioners in doing this might well be a reason why funding bodies and research panels are less familiar with these possibilities, and as such would find it easier to fund a project like the one Croft describes to do with 'sustainability'. Unlike Croft, however, I do not believe it is impossible to make a convincing case for the originality of musical material, or interpretive approaches, but more practitioners need to try doing this more often. Croft asks whether a composer's work is 'helped in any way by the thought that it is research, or the presentation of research "findings"?', but these are selfish reservations, as such reflection might well help others too. Composers may wish to be paid a salary to compose or perform in the way they always have done, but perhaps they would then be better employed on a teaching contract for composition with the recognition and remuneration for their composition or performance coming from elsewhere.

The problem of research funding becoming a major yardstick for progression in the modern university is a very real one, especially as funds become scarcer, but is beyond the scope of this article. Nevertheless, outside academia it is commonplace to seek money for practical projects and the criteria involved can be just as narrow and constricting, as well as more susceptible to the personal whims of those involved with funding bodies who are not required to be transparent or accountable about their criteria. At a REF panel discussion in February 2015, it was argued that the REF can entail a large amount of financial support for innovative practice-based work. ${ }^{25}$ There remain various obstacles towards achieving this (not least from individual institutions inclined to downgrade practice-based work in general), but it is not an unrealistic goal. If this requires practitioners to articulate ways in which their work has value and consequences not just in and of itself but also to others as a contribution to knowledge, this seems a fair price to pay.

Croft's description of research as something which 'describes' rather than 'adding something to' the world is also too narrow, and it suggests categories beholden to analytical philosophy (notwithstanding the references to Gadamer, Schopenhauer, Langer and Heidegger) and a Popperian view of scientific knowledge which has been cogently argued against by Hazel Smith and Roger T. Dean. ${ }^{26}$ Those who

${ }^{25}$ Discussion on 'Survival of the Fittest? Promoting Dance, Drama and Music through UK Higher Education', Institute of Musical Research, London, Saturday 28 February 2015. I was unable to attend this, but am grateful to Roddy Hawkins for letting me see his notes from the occasion. 
develop a new type of drug to ease aging symptoms, find a new bridge structure (in the engineering rather than musical sense of the term) which is not only aesthetically striking but also secure, are obviously adding something to the world not wholly unlike what a composer or performer might do, but those who provide a vivid and well-sourced portrayal of everyday life and cultural practices in a fifteenth-century Sicilian village, or posit a type of dinosaur which none have previously imagined, are not merely describing but shaping and constructing the world. Even musical analysis, not to mention contextual, historical and sociological study, adds something to experience, at least for me; not all literary study might be as boldly creative as Benjamin on Baudelaire, or Barthes on Balzac, ${ }^{27}$ but these examples show how such study can be an immensely creative practice itself.

I cannot at all accept Croft's portrayal of either scientific or musical discoveries. It is by no means necessarily true that, as Croft says if Einstein had not existed, someone else would have come up with Relativity'; someone might have come up with a quite different, but equally influential paradigm. Yefim Golyshev and Josef Matthias Hauer came up with ways of using twelve-note rows very different from those of Schoenberg; ${ }^{28}$ the history of modern music is beholden not simply to a phenomenon that Schoenberg happened to chance upon, but to a very particular individual approach. Without the person of Schoenberg, twentieth-century music history might have been very different, and twelve-tone music a minor development known only to a few people interested in Golyshev and Hauer. It is certainly simplistic to say that Schoenberg would 'correct and supersede Bach', but the assumption that science follows a model of linear progress is not much better. There may be a reason we prefer Darwin to Lamarck, but there is also a reason why the apparent scientific 'progress' represented by racial theories of Social Darwinism can be viewed as a retrogressive step compared to what preceded it. Similarly, there is such a thing as 'good music badly composed': an obvious example would be music marred by a lack of understanding of some of the physical characteristics of particular instruments, which can however be improved with some care and instruction (and maybe that dreaded collaboration with a performer).

There is a good deal of practice-based research, some of it published in verbal form, which undoubtedly devalues the whole concept:

${ }^{26}$ Smith and Dean, 'Introduction', pp. 3, 6-7. Smith and Dean argue for the vital role for the creative arts of knowledge which is neither verbal nor numerical, in which context should be viewed artistic work as research; this is entirely consistent with the types of research which have made up a large percentage of REF submissions in music and other performing arts.

27 Walter Benjamin, The Writer of Modern Life: Essays on Charles Baudelaire, translated Howard Eiland, Edmund Jephcott, Rodney Livingstone and Harry Zohn (Cambridge, MA: Harvard University Press, 2006); Roland Barthes, S/Z: An Essay, translated Richard Miller, with preface by Richard Howard (New York: Farrar, Straus \& Giroux Inc, 1991).

${ }^{28}$ For detailed considerations of the huge differences between Hauer and Schoenberg's approaches, see Dixie Lynn Harvey, 'The Theoretical Treatises of Josef Matthias Hauer', (PhD Dissertation, North Texas State University, 1980), pp. 21-37 and Deborah H. How, 'Arnold Schoenberg's Prelude from the Suite for Piano, Op. 25: From Composition with Twelve Tones to the Twelve-Tone Method', (PhD Dissertation, University of Southern California, 2009), pp. 45-9, 58-65, 125-223; on Golyshev, see Detlef Gojowy, 'Jefim Golyscheff - der unbequeme Vorläufer', Melos/Neue Zeitschrft fur Musik, May 1975, pp. 188-192, 'Frühe Zwölftonmusik in Rußland (1912-1915)', Beiträge zur Musikwissenschaft 32/1 (1990), pp. 17-24; and Neue sowjetische Musik der 20er Jahre (Regensburg: Laaber, 1980), pp. 102-3; and my 'Yefim Golyshev, Arnold Schoenberg, and the Origins of Twelve-Tone Music' (2 September 2014), at https://ianpace.word press.com/2014/09/02/yefim-golyshev-arnold-schoenberg-and-the-origins-of-twelve-tonemusic/ (accessed 6/9/15). 
especially various manifestations of the frequently narcissistic practice sometimes called 'auto-ethnography'. ${ }^{29}$ These include often unremarkable 'performance diaries', given some apparent theoretical weight by the mention of a few treatises and other texts, texts from composers reproducing long letters or e-mails between composer and performer/dancer/film-maker, or new work deemed distinctive and research-like simply by virtue of the use of one or two unusual techniques, or a less familiar instrument. Nor does musical practice become research simply by virtue of being accompanied by a programme note, which funding and other committees can look at while ignoring the practical work.

The major problem is surely not whether outputs in the form of practice can be research but how we gauge equivalence with other forms of research, when practitioners and other academics are all competing within the same hierarchical career structures in universities. I have some doubts as to whether some composition- and performancebased $\mathrm{PhDs}$, especially those not even requiring a written component, are really equivalent in terms of effort, depth and rigour with the more conventional types. ${ }^{30}$ Other inequities exist: composers and performers often teach 'academic' subjects in university music departments, but rarely are non-practitioner academics deemed able to teach high-level composition or performance. This can contribute to the downgrading of more traditional approaches to research, compounded by the inconvenience of the time they require especially those that require mastery of foreign or archaic languages, ${ }^{31}$ or lengthy trips to remote locations - in an era when academics' time is squeezed ever more. Institutions may prefer to employ someone who can produce a composition in a few months, rather than taking a year over a major article or book chapter that requires much preliminary groundwork.

However, issues of equivalence can also drive wedges between academics producing different types of textual outputs: I have difficulty accepting an equivalence between many essays in the field of popular music studies (many of them saying a minimal amount about the sounding music) that rehash the ideologies and paradigms to be found in any cultural studies primer, with detailed, painstaking and highly specialised study of medieval musical manuscripts, subtle exegeses of musical practices in remote communities, or sustained

29 A defence of auto-ethnography can be found in Freeman, Blood, Sweat \& Theory, pp. 181-4, which acknowledges the type of danger I mention above, which has been addressed earlier, with some suggestions for avoidance of narcissism and self-indulgence, in Amanda Coffey, The Ethnographic Self: Fieldwork and the Representation of Identity (London: Sage, 1999) and Nicholas L. Holt, 'Representation, Legitimation, and Autoethnography: An Autoethnographic writing story', International Journal of Qualitative Methods, 2/1, Article 2 (2003), at https://www.ualberta.ca/ iiqm/backissues/2_1/html/holt.html (accessed 6 September 2015).

${ }^{30}$ Paul Draper and Scott Harrison, in 'Through the Eye of a Needle: the Emergence of a Practice-Led Research Doctorate in Music', British Journal of Music Education, 28/1 (2011), pp. 87-102, make a strong case for practice-as-research in the Australian DMA; this is quite different to a lot of other programmes of this name, though, because of the requirement of a minimum of five years professional experience and frequently a formal research qualification. Other performance-based DMAs I have encountered have frequently involved just a loosely-linked recital and thesis more appropriate for a Bachelor's or Master's degree.

${ }^{31}$ For an examination of how various supposedly multicultural, new musicological, and popular and film music studies work entails a retreat from engagement with multilingual sources (especially ironic in the case of that accompanied by rhetoric of difference, 'others' and multiculturalism), see my 'Multicultural Musicology for Monolingual Academics?' (22 April 2015), at https://ianpace.wordpress.com/2015/04/22/musicological-observations-3multicultural-musicology-for-monolingual-academics/ (accessed 6 September 2015). 
application of sophisticated analytical techniques to already-complex music. But the former may receive a comparable REF ranking when judged by peers engaged in work of a similar nature; the result could be a regrettable deskilling of the academic study of music.

For me, learning and performing repertoire both new and old has often been accompanied by questions for which I have to find answers, by studying compositional structure, style, genre, allusions, and all the forms of mediation which accompany these, then making decisions about which aspects to foreground, play down, elicit, how doing all this in a manner with which will be meaningful to listeners. If I say that I have learned a good deal from listening to performances and recordings of Walter Gieseking, György Cziffra, Charles Rosen, or Frederic Rzewski, or Barbara Bonney, or Nikolaus Harnoncourt, or even Marcel Pérès, this is not simply in the sense of old-fashioned conceptions of 'influence' and osmosis (not that these do not also occur). I listen to these performers to garner some idea of what is distinctive about their approach, and how they have set about achieving this. In a critical, non-slavish manner it is then possible to draw upon their achievements and also to discern what other possibilities might exist, opening up a new range of interpretive - and I would say research - questions.

This approach is at odds with nebulous ideals of instinct and inner authenticity, or (worst) with the search for the style required to make a success (though this is itself also a form of research), the most dispiriting aspects of music school, conservatoire and some parts of the profession. But my approach is far from uncommon, and in this sense the articulation of practice in research terms is a positive and productive activity. ${ }^{32}$ It may be less spectacular than some of the wilder fringes of theatre and visual performance - such as Lee Miller and Joanne "Bob" Whalley's joint $\mathrm{PhD}$ project, collecting urine-filled bottles on the M6, replacing them with other detritus, renewing their wedding vows in a service station, then grounding this in the thought of Deleuze and Guattari, Bakhtin, dialogism, heteroglossia and semiotic multi-accentuality, deliberately framed in such a way as to frustrate Popper's criteria of falsifiability ${ }^{33}$ - but is no less 'research' as a result.

Unlike Croft, I believe that composition-as-research, and performance-as-research (and performance-based research) are real activities; the terms themselves are just new ways to describe what has gone on earlier, with the addition of a demand for explicit articulation to facilitate integration into academic structures. This process is made problematic by other factors but that is no reason to give up on the best ideals.

Croft argues that we should 'guard against actually believing in our research narratives'; I believe we should guard against believing in myths of compositional autonomy and individualism, and be less surprised when demands to do whatever one wants, whilst being paid reasonably generously for it out of the public purse, fall upon deaf ears.

32 As Andrew R. Brown and Andrew Sorensen put it well, 'There is a general way in which research is a part of many activities. In this general way, research refers to the act of finding out about something and is involved in learning about a topic, extending a skill, solving a problem and so on. In particular, almost all creative practice involves this general type of research, and often lots of it' ('Integrating Creative Practice and Research', p. 153).

33 See Lee Miller and Joanne 'Bob' Whalley, 'Partly Cloudy, Chance of Rain', in Freeman, Blood, Sweat \& Theory, pp. 218-31 on this project. For an account of its examination, see Kershaw, 'Practice as Research through Performance', pp. 108-13. 